\title{
A review of institutional response and Covid-19 pandemic risk communication in regional autonomy system in Indonesia
}

\author{
Agus Supriyadi a,b,1,*, Tao Wang a,b,2, Pandu Pribadi ${ }^{c, 3}$, M. Ali Mauludin ${ }^{\mathrm{d}, 4}$, Faqih \\ Ma'arif ${ }^{\mathrm{e}, 5}$, Zalik Nuryana ${ }^{\mathrm{f}, \mathrm{g}, 6}$ \\ ${ }^{a}$ The School of Geography, Nanjing Normal University, Nanjing 210023, China \\ ${ }^{\mathrm{b}}$ The Jiangsu Center for Collaborative Innovation in Geographical Information Resource Development and Application, Nanjing 210023, China \\ ${ }^{c}$ STIT Muhammadiyah Banjar, Banjar 46331, Indonesia \\ ${ }^{\mathrm{d}}$ Laboratorium of Sociology and Extension, Padjadjaran University, Indonesia \\ ${ }^{\mathrm{e}}$ Department of Transportation Science and Civil Engineering, Beihang University, Beijing 100083, China \\ ${ }^{\mathrm{f}}$ School of Education Science, Nanjing Normal University, Nanjing, 210097, China \\ ${ }^{g}$ Universitas Ahmad Dahlan, Indonesia
}

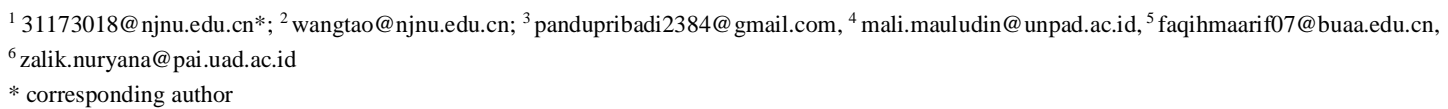

\section{ARTICLE INFO}

\section{Article history}

Received 2020-10-08

Revised 2020-11-23

Accepted 2021-01-08

\section{Keywords}

Covid-19

Regional Autonomy

Political Ecology

Risk Communication

Indonesia

\section{ABSTRACT}

A global pandemic Covid-19 led countries to take aggressive action regarding social management and crisis governance management system. The case of a pandemic discovered in Wuhan provides a lesson for the government worldwide to adopt. However, the government system in every country has its characteristics. This study aims to release the potential policy recommendation in Indonesia when Indonesia's regional autonomy system faces a challenge in the pandemic situation, such as the increase of competition between regions. Even more, the public service system becomes concerned with the ego regionality. The strengthening country's capacity system is vital in the regional autonomy system as well as the collaboration between central and local government in terms of containment of the spread of the pandemic. Used a political ecology approach and a descriptive- review method, this study was conducted by discussing how the government responds in the regional autonomy system at the beginning of the pandemic situation. The review results show that the local government's response relies on their capacities, such as budget, human resources, and leadership. However, challenges arise when central and local governments' action is not in line in terms of the regional autonomy system. The public and political communication among central and local governments should be rearranged with an integration under proper management, particularly in the first month of the pandemic situation.

This is an open access article under the CC-BY-SA license.

\section{Introduction}

A global pandemic Covid-19 encourages many countries to change their perspective regarding society management and crisis governance management system. The first case of a pandemic discovered in Wuhan provides an illustration of the enormity of the impact on the Chinese economy. However, this pandemic also gives lessons to countries in the world on how important crisis management is to maintain its citizens' survival and economy. For countries with a centralized 
system of governance, managing crisis management may not be a significant obstacle. On the contrary, developing countries such as Indonesia that are still proceeding in a decentralized governance system have extraordinary challenges in coordination with the local government, particularly when an imbalance in local government capacity occurs. When an influenza pandemic emerges, the lesson that can be learned is that many countries are not ready to anticipate it because of the unpreparedness of the health system in their country to prevent the spread of outbreaks that occur [1], [2].

Since the transformation of the government system implemented in Indonesia which followed by an unprecedented rate of the land use at the expense of a continuous shrinkage of agricultural and unused land, which has led to a series of problems, such as increasing ecological insecurity, politic and intensifying social conflicts [3]-[6]. In a public policy theory, it is important to prepare the impact that will arise after the policy is implemented. Regional autonomy policy in Indonesia has invited a lot of discussion from the scholars, even Miller (2013) in her research stated that Indonesia is the largest laboratory in the world in the implementation of regional autonomy theory. However, the effectivity of management crisis in regional autonomy era is still questionable.

The biggest challenge in a decentralized government system that arises is that the administrative system that is tiered from the central government to the lowest level of government has caused a miss communication between regions. In addition, in Indonesia's regional system of autonomy, regional authority is still limited by rules related to national interests. This condition causes the regional government not to act quickly to minimize the spread and reduce the impact of a pandemic or even endemic. Previous literature mostly discusses the implementation of regional autonomy in Indonesia seems to focus more on the system, its implementation and legally legal [7]-[10]. The debate about potential and challenges with the implementation of regional autonomy in Indonesia is seen in previous literature on driving forces and mechanisms behind the regional autonomy policy. However, a great discussion arises when a huge challenge occurs such as a global pandemic situation, how are the governance system will react and respond. This paper does not intend to provide an exhaustive list of the responses, but it aims to capture current challenges and local government-led responses in the middle of the crisis. This paper discusses the challenges how the regional autonomy system in Indonesia in response to the Covid-19 pandemic situation in political ecology perspective. The methodology for review used in this study by observing various social media platforms is available from January to April 2020 It will also include rapid analysis based on an analysis of two national media content, including speeches and reports which focus on risk communication and public engagement.

\section{Literature review}

\subsection{Regional autonomy in Indonesia}

As one of the largest population countries in the world, Indonesia has undergone rapid and sustained economic growth and urban development in the past several decades. Since the fall of the New Order government in Indonesia has led to significant changes in governance, which were initially centralized under the regional autonomy system, place regional governments in taking wider action in terms of governance management in their regions. This system led transformation management in many fields, including the health management system. However, the regional government system also triggers differences of opinion related to the limited authority of the region in making policies to deal with cross-sectoral issues.

At first, regional autonomy policy is a policy that arises from the occurrence of imbalance development in Indonesia. This condition is supported by the diversity of its history, ideology, culture and religion in every region in Indonesia. Therefore, the development of areas that are centered by the central government is considered not to accommodate local wisdom[11]. Geographically, Indonesia is a country with a large population which is also the largest archipelago in the world, causing government management to tend to require governance innovation based on regionalism [12]. The complexity and diversity that exists in Indonesia is a challenge in managing this country. Often conflicts occur due to regional differences. Therefore, the development of an area can be obtained when the development planning program is aligned with local wisdom and the 
needs of the local community. This is what makes the importance of sharing roles between the central government and regional governments.

Since the regional autonomy policy implemented, autonomous urban areas in Indonesia meet opportunities and challenges simultaneously [8], [13]. This condition indicates that the regional division of authority to the regions encourages the growth and development of the city that is more in line with the needs of the region itself. However, this condition also encourages an increase in competition between regions. Moreover, the public service system becomes inclined to be concerned with the ego regionality [9], [14]-[17] [6]. However, a new challenge for regional autonomy system tested by the global pandemic of Covid -19around the world.

In the era of regional autonomy, regional authorities' political ecology was considered to trigger significant environmental problems. Regional authority and regional political actors have a strong influence in intervening in public policies from the planning, implementation, and control of development stages, including the management of natural resources and the environment. It was supported by the additional limited authority in natural resource management and environmental management, which resulted in a terrible ecological crisis [18]-[20].

One of the essences of regional autonomy in Indonesia is public service and wider community participation and involvement in the development process. Thus, this government system makes the local government crucial in direct relations with the community. Furthermore, regarding urban and rural development planning for public services to work well, two factors are needed that must be of primary concern. First, the bureaucratic apparatus's capacity that supports the main tasks and functions. The second factor is the regional leader's leadership as a political actor determining regional policies [21].

\subsection{COVID-19 and a pandemic lesson from the past}

The pandemic's enormous spread is a strong challenge that led governments worldwide to aggressively take action to control the spread of this disease by being forced to put aside economic growth in 2020 [22]. In the case of a pandemic situation, previous research has shown that politics has become an important key in many ways, especially concerning the impact that will occur during and after a pandemic. Despite the differences from previous pandemic cases, the spread of Covid-19 that can be transmitted from humans is frightening and quite challenging for governments anywhere in the world to control without causing a large economic impact. Evidence in previous literature has shown that pandemic governance faces challenges and obstacles globally, so a pandemic handling system must be structured and structured using the power and strength. Experience from a previous influenza pandemic in 2007, where the world health organization (WHO) declared as the most feared was pandemic influenza. Its ability to spread easily between humans, the difficulty in controlling it, and the number of fatalities inflicted by previous outbreaks, epidemics, and pandemics [23].

The importance of sustainable policy can be seen in previous evidence when unexpected health system policy changes led to a large outbreak of poliomyelitis across northern Nigeria. The reinfection of previously polio-free areas south of the country occurred [2]. Empiric evidence in influenza pandemic in 2009, in most cases the government will responses aligned with the recommendation from organization such as $\mathrm{WHO}$ and adhered to the recommendation of medical experts and best practice guidelines for pandemic cases [1]. However, strengthening the country capacity system is also important in preventing and containing the spread of the pandemic; otherwise, pandemic management guidelines will not have a significant effect. Another lesson in the case of endemic Ebola in Africa is when the authorities' capacity does not have adequate capabilities. It tends not to place an endemic as an extraordinary event that drives the potential danger that might occur will be even more significant [24].

Frame in global health governance is an important issue in a case of pandemic disease because when a frame has been raised, the policy response that arises will also lead to the existing structure [25]. Therefore, a policy must be prepared carefully by considering the effects of a health policy framework based on interests. An important finding in a study where research using vaccine application modeling variables for $60 \%$ of the American population on the economic impact arising in a pandemic that the fastest rate of economic recovery is when there is an intervention in 
prevention of the deaths [26]. Learning from this condition, a government need to restore economic growth faster recovery requires intervention to move more massively prevent mass death.

A previous research in The Great Britain in terms of critical bed occupied during pandemic situation indicated that when the government to late in taking action in the beginning or do nothing, as can be seen in fig .1. The curve of critical beds occupied reach the highest peak, and when the action taken by case isolation, home quarantine and social distancing of 70's, the curve is in the lowest peak [22]. In this situation, the government and the country's people need to understand and work together in the mitigation and suppression strategy. To invite the public to be involved and willing to cooperate, it becomes crucial in the role of risk communication or public communication carried out by the government, as well as consistent enforcement of regulations.

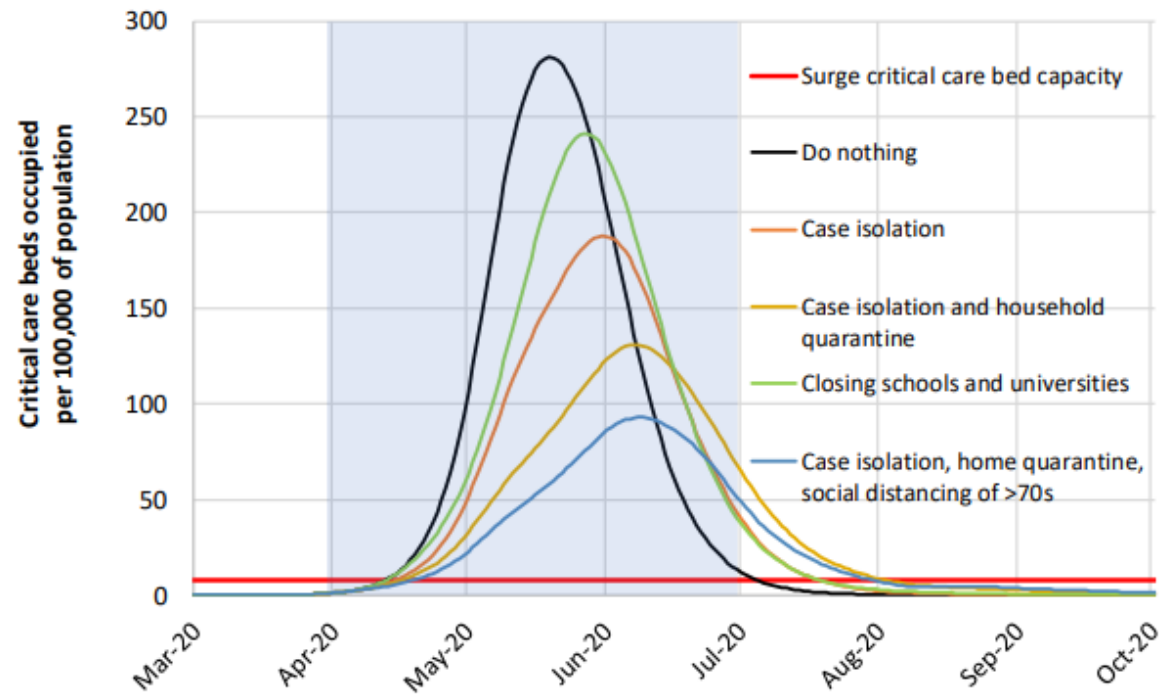

Fig. 1. The critical beds occupied per 100.000 of population incorrelation with the government action (source Neil M Ferguson, Daniel Laydon, Gemma Nedjati-Gilani et al [22])

\subsection{Mass Public Communication Literatures}

Delivering information to the public requires public officials' ability and expertise to understand the science of communication. Communication science is theoretically a systematic step in an effort to rigorously formulate the principles or guidance in transmitting information that also contains the credibility of the informant, opinions, and attitudes formed after the information is conveyed [27]. Therefore, referring to this definition, in public information delivery, it is important to prepare in advance the scenario of the informant, the media, the expected effects, and the steps to deliver the information. In a pandemic case that requires comprehensive handling, the delivery of information will involve the interests of the political, social and economic environment of risk communication. Therefore, a simultaneous and sustainable public communication campaign is necessary [28].

Public communication campaign can be defined as purposeful efforts to educate or affect broad audience actions within a given period of time using a coordinated series of communication activities and a variety of mediated communications on multiple platforms to achieve noncommercial benefits for individuals and society in general [28], [29]. Furthermore, in the situation and era of globalization, the roles of social media and mass media are inseparable in the process of delivering information to the public. Therefore, in a pandemic situation, the use of social media and mass media requires a unique strategy designed and built by implementing continuous official information monitoring. Although basically, the use of social media and mass media in the delivery of public information is an approach in media-centric communication theory [30], in the case of a pandemic, the integration of media and community-centric approaches is one of the alternatives for good steps in an effort to achieve successful delivery of public information. 


\subsection{Political Ecology and Communication Practise}

Human interaction with nature is a necessity that cannot be separated. The fact is that in development in the city, there is almost certainly a development that is forced to disrupt or change nature to adjust to human behavior. The growth of urban areas will directly change the existing land use. However, urbanization is not merely a linear distancing of human life from nature, but rather a process by which new and more complex relationships of society and nature are created [31]. ]. The definition of ecology as "the science of economy of the animals and plant" is a branch of biology that deals with organisms' relations to their surroundings, habits, and modes of life that have encouraged the dominance of human studies interaction with the environment. The natural surroundings or the impact it causes [32]. In its application in a community, the role of the authority to be able to utilize its power in regulating the interaction between living things and their environment, this is where the role of political ecology.

In recent decades the world seemed to face challenges with more and more frequent outbreaks of disease. This condition certainly has a significant impact in each country, responding to this situation, which considers many things both economically and "politically" [33]. Pandemic preparedness is not merely a technical problem but will be related to politics and normative. Solving a disease outbreak cannot be resolved only by applying health theories or guidelines for behaving, but requires an effort from the government and society [34]. Therefore a government system need to work together and coordinate inter-department and globally in an effort to deal with the spread of an epidemic [35]. Furthermore, the importance of understanding and controlling the behavior of population movements between regions is also the key to the success of an area or the government inhibits or even reduces the spread of a pandemic whose transmission is through the media of human intermediaries.

The lesson from China is how the role of political power by implementing very large restrictions on movement. After implementing control measures, the spread of Covid-19 decreased. The growth rate became negative in most locations, indicating that China's drastic control measures substantially reduced the spread of Covid-19 [36]. Another important thing is that political communication and public communication need to be built systematically to deliver information to the public about the dangers of an outbreak and transmission potential. In this case, in addition to the role of mass media or electronic media, it seems that social media also contributed quite important to disseminate information [37].

\section{Covid-19 pandemic case in Indonesia and Government response in first period of spreadness}

Handling cases of the spread of Covid-19 involving human interaction prompted governments worldwide to implement strict rules of activity for their citizens. As was done in Wuhan China, how the Chinese government closed access to and from this city. In Indonesia, after discovering the first Covid-19 positive patient occurred on 2 March 2020 in Jakarta, the Indonesian government responded by isolating the patient and disseminating it through the Ministry of Health. The government traced existing positive patients and carried out the steps in independent isolation recommendations for people who feel they have interacted with these positive patients. The development of the number of patients with positive coefficient Covid-19, as shown in the following Figure 2.

Actions by the central government began with a travel restriction from Hubei province on 27 January 2020, which was at the time, the epicenter of global Covid-19, together with the evacuated 238 Indonesians from Wuhan. However, the official response of the central government in Indonesia in handling Covid-19 began with the decree of the minister of health no HK.01.07 / MENKES / 104/2020 on February 4, 2020. It contains four steps for handling: improving communication, information, education on public health, preparedness for entry from abroad and regions, preparing health facilities and supporting logistics, and coordinating across sectors. Decisions that still generally do not contain detailed steps will and should be made at the local government level. Therefore, except for Jakarta as the country's capital city until the beginning of March, practically there is almost no readiness done in real by the local government in Indonesia. 
Because of avoiding causing panic in the community, the public communication conveyed during the press release of the spread of corona's spread until the end of February caused a paradigm in the community that this pandemic is not something to be afraid of and is considered a selflimiting disease. This both, directly and indirectly, led to a lack of public awareness of the dangers of Covid-19. On the other hand, practically at the regional government level, except the Capital of Jakarta. None of the local governments take real action in terms of the prevention of the spread.

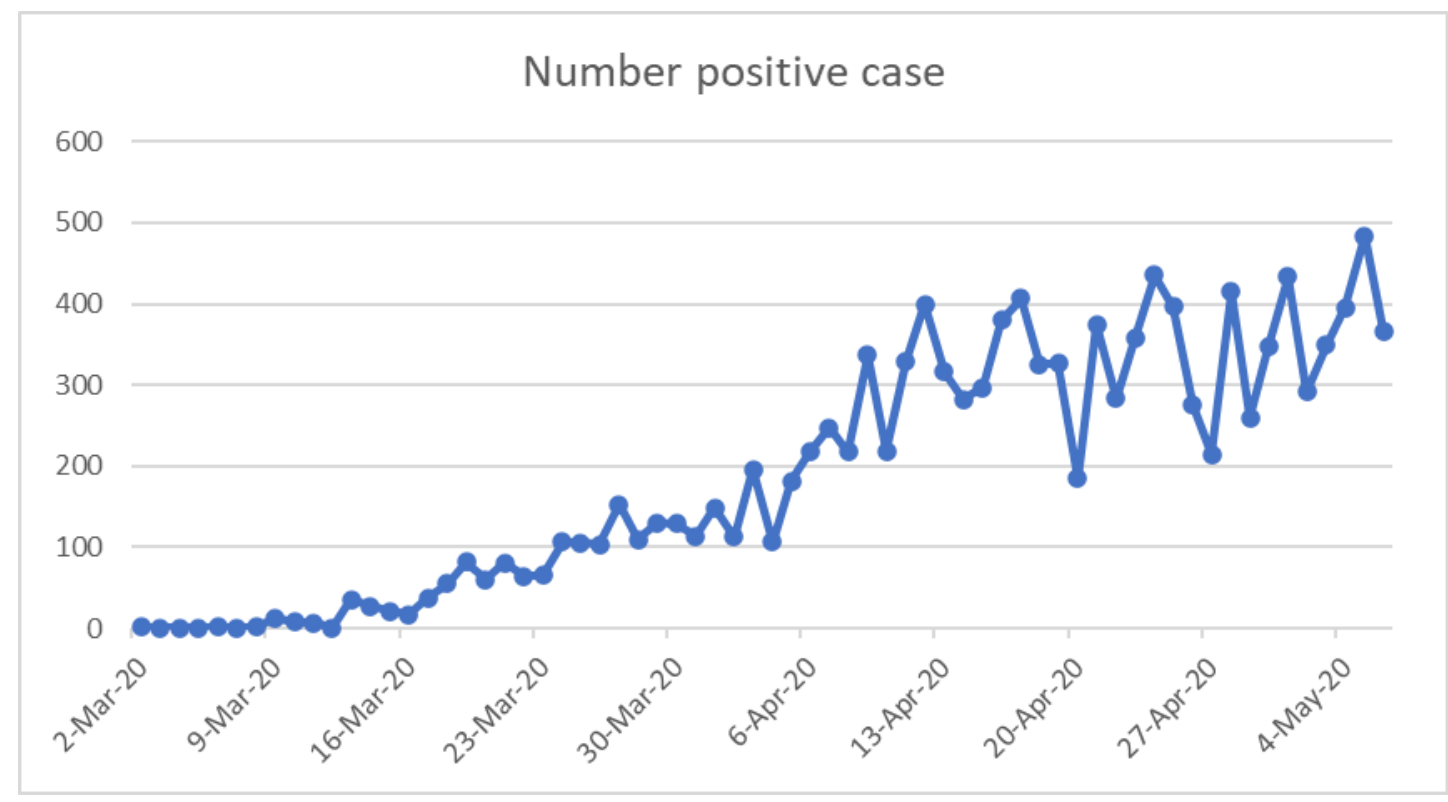

Fig. 2. The number of positive confirmed cases

On 27 February, the National Disaster Management Agency (BNPB) declared a special emergency, followed by the announcement of the first Covid-19 case in Indonesia by the President of the Republic of Indonesia on 2 March 2020. Emergency systems and regulations at the national level have already been prepared. On the same date, the governor of Jakarta was a press conference about the steps to be taken and organized by the Provincial Government of DKI Jakarta.

\section{A Review and Discussion}

The rapid development of Covid-19 distribution has prompted WHO to issue interim guidance on Critical preparedness, readiness and response actions for Covid-19 which contains priority areas that need to be carried out in handling, and anticipating the spread of Covid-19 as follow: emergency respond mechanism, risk communication and public engagement, case finding and tracing, surveillance, public health measure, strengthening the health human resources capacity, laboratory testing, case management strategy and societal response [38]. In this discussion the analysis is carried out with reference to the guidance issued by WHO, linked to the response of the central and local governments in Indonesia, through the perspective of political ecology.

\subsection{Institutional Response}

Since Covid-19 was first announced in Wuhan following the closure of population access and movement in the city in February, practically no meaningful response by the Government of Indonesia in terms of the local government's readiness in a situation likely to face a pandemic. Except for the preparation of the repatriation of Indonesian citizens currently in Wuhan. Although on February 4, it has determined the steps to be taken in anticipating the pandemic case that discovered in Wuhan, however, in practice, preparations for supporting institutions have not been fully prepared. It can be seen that the issuance of this Ministerial decree was not followed up with policies up to the local government level, it resulted in minimal preparedness and anticipation carried out and prepared at the local government level. 
Table 1. National government and local government response in Covid-19 pandemic

\begin{tabular}{cl}
\hline \multicolumn{1}{c}{ Date } & $\begin{array}{c}\text { Government response on } \\
\text { Covid-19 pandemic }\end{array}$ \\
\hline 04 February 2020 & $\begin{array}{l}\text { The four steps of handling } \\
\text { novel 2019-nCov } \\
\text { Declaration of novel 2019- } \\
\text { nCov as disease can cause } \\
\text { plague and its response }\end{array}$ \\
& $\begin{array}{l}\text { measures } \\
\text { Declaration of Special } \\
\text { Emergency Situation of Covid- } \\
\text { 19 Earch 2020 } 2020 \\
\text { Indonesia Disaster in }\end{array}$ \\
02 March 2020 & $\begin{array}{l}\text { Press release first confirm } \\
\text { Covid-19 case }\end{array}$ \\
&
\end{tabular}

13 March 2020

14 March 2020

16 march 2020

16 March 2020

17 March 2020

18 March 2020

18 March 2020

19 March 2020

19 March 2020

20 March 2020
Press conference from governor of Jakarta for Jakarta preparedness on Covid-19 situation

Task Force for Rapid Response to

Covid-19 pandemic

Distribution of Special Grant Allocation for Infrastructure in Health Sector and Grants for Health operation for Covid-19 Indonesia announced that it will start to quarantine asymptomatic Covid-19 patients in their own home Network of Covid-19 Laboratories

In response to the growing number of Covid-19 cases in Indonesia, the Indonesian National Board for Disaster Management declared an emergency period for 91 days, effective until 29 May 2020

After 2 positive cases,

Governor of West Kalimantan Sutarmidji declares an "extraordinary event" until further notice

First death positive cases, press release Governor of Banten however the National speaker declared do not know the case Prohibition of mass gathering or group activity both in public and local environments

Joko Widodo announces 7 critical points (mass rapid tests, incentive for medical personnel, involve religious people, stop exporting medical equipment, stop holiday, incentive for small and medium enterprises, increase food stocks) to accelerate the elimination of Covid-19 outbreak in Indonesia

\section{Reference}

The decree of the minister of health no HK.01.07 / MENKES / 104/2020

Decision of MoH No: HK.01.07/MENKES/104/2020

Decision of Head of BNPB 9A/2020

https://www.straitstimes.com/asia/se-asia/indonesiaconfirms-two-coronavirus-cases-president https://indonesia.go.id/narasi/indonesia-dalamangka/ekonomi/kasus-Covid-19-pertama-masyarakatjangan-panik

https://news.detik.com/berita/d-4921925/anies-soalpenanganan-corona-sampai-siang-ini-136-orang-dipantau

Presidential Decree (Keppres) No.9/2020

Decision of MoF 6/KM.7/2020

https://news.detik.com/berita/d-4941325/kemenkessekarang-pasien-positif-corona-bisa-diisolasi-mandiri-dirumah

Decision of MoH HK. 01.07/MENKES/182/2020

https://news.detik.com/berita/d-4942327/pemerintahtetapkan-masa-darurat-bencana-corona-hingga-29-mei2020?tag_from=news_mostpop

https://news.detik.com/berita/d-4944658/ada-2-kasuspositif-gubernur-tetapkan-kalbar-klb-corona

https://news.detik.com/berita/d-4943106/gubernur-bantenumumkan-1-warga-positif-corona-meninggal-kemenkestak-tahu

Kapolri Mandate No. MAK/2/III/2020

https://nasional.kompas.com/read/2020/03/19/15282081/7 arahan-terbaru-jokowi-untuk-penanganan-Covid-19 https://news.detik.com/berita/d-4945259/ini-arahanlengkap-terbaru-jokowi-untuk-tangani-virus-corona 
21 March 2020

23 March 2020

24 March 2020

28 March 2020

31 March 2020
Revision of Keppres on Task Force for Rapid Response to Covid-19

Refocussing of activities, fiscal allocation and procurement of goods and services for the acceleration

The Governoor Jakarta declare Covid-19 emergency situation and restrictions activities for 14 days

The Governoor of East Java declare Covid-19 emergency situation

Tax incentives for Compulsory Tax Holders affected by Covid19

Acceleration of socialisation of Covid-19 Prevention at Provincial and District/City levels

Village Response for Covid-19 and Cash for work in Villages

The mayor of Tegal municipality closed acces for the city preventing the spread of Covid-19 and the National speaker explain it was not a lockdown policy only a limitation access

National Budgeting Policy and the Stability of Budgeting System for Covid-19 Pandemic Disaster and/or Managing Threats for National Economy and/or the Stability Budgeting System

Declaration of Community

Health Emergency Situation for Covid-19

Big Scale Social Restriction for Accelerating Covid-19 Eradication
Presidential Decree (Keppres) No.9/2020

President Instruction (Inpres 4/2020)

https://www.thejakartapost.com/news/2020/03/20/breakingjakarta-declares-Covid-19-emergency-urges-offices-tosuspend-operation-for-14-days.html

Decree of the Governor of East Java Number 188/108 / KPTS / 013/2020, and referring to the Decree of the Head of BNPB Number 13.A / 2020

https://regional.kompas.com/read/2020/03/20/18240621/9orang-positif-Covid-19-khofifah-tetapkan-jatim-daruratvirus-corona.

The Minister of Finance Regulation No: 23/PMK.03/2020

The minister of Communication and Information Circulated letter SE 2/2020

The Minister Village, Regional Disadvantage and Transmigration https://news.detik.com/berita/d-4956263/bnpb-kota-tegaltidak-lockdown-kereta-masihlewat?_ga=2.15755702.1807186802.15926670261956474417.1564550720

Government regulation in Lieu of Law No 1/2020

President Decree No 11/2020

Government Regulation No 21/2020 
The central government's response is more of a minimum nature, as indicated by only two sectoral regulations issued. First is the declaration of Ministry of Health Novel 2019-nCov as a disease that outlines the potential transformation of Covid-19 into an outbreak and what can be done on February 4, 2019. Second, the national declaration on the special emergency of Covid-19 by the head of BNPB on February 27, 2020 [37]. In February, there were practically no regulations governing how local governments took preventive actions. Furthermore, Table 1 shows that most of the regulations were issued after March 13, when the President formed the Task Force in which the head of the National Disaster Management Authority (BNPB) was appointed as commander.

Based on the condition of the first positive confirmed case in Indonesia, the local government's response has taken tracing and curative measures such as by setting up several referral hospitals specifically handling Covid-19 patients and increasing the capacity of the medical staff who handle these patients. Furthermore, through the Covid-19 handler, the task force presents daily developments and preventive appeals to prevent the spread of this pandemic throughout the region. However, being an archipelagic country, the biggest obstacle is the unequal health infrastructure and the limited ability of regional resources. Therefore, based on this situation, it is important that the effort to contain the virus's spread to areas that do not have supporting health infrastructure. It seems that in the first period, which was crucial in anticipating the spread of the virus, there were no specific preparations for how to prepare local governments to face the possibility of the spread of the Covid-19.

Sociologically and culturally, people in Indonesia and each region have different characteristics and behaviors. A structural approach is theoretically crucial because it involves sociological, historical, political, and economic approaches in making policies [35]. It is important to react quickly by the government to contain the spread. The lesson that can be taken from the world's first case discovered in Wuhan is the Chinese government's quick reaction to isolating the disease's epicenter. Still, it seems that if we refer to the socio-cultural Indonesian people, this step will face quite a tough challenge. Besides, the regional autonomy system gives authority to regions to regulate their territories, making the central government need to carry out a long enough coordination.

Coordination is quite a challenge in the era of regional autonomy. The case that has become a lot of discussion is when the Jakarta Special Capital Region Government tried to limit public transportation in the early days of the pandemic, which was eventually canceled by the central government because it was deemed inappropriate. The regional government is still obliged to provide public transportation even in a pandemic situation. Based on this, it can be seen that institutionally the regional autonomy system is not ready to face cases of extraordinary events such as this pandemic.

\subsection{A review of Pandemic Public Communication}

The appointment of a task force to handle the Covid-19 pandemic is an essential strategic step to curb this disease's spread. However, the task force is a cross-sectoral organization structured by a hierarchical organization linked to various cross-regional governments and ministries. Therefore the problem that arises is that coordination and handling authority collapsed by the regional autonomy government system, which requires a tiered coordination span. One of this task force's tasks is to convey the development of pandemic situation and steps taken by the government to the public. Accordingly, that information can reach the public and affect the community in changing behavior and contain the spread of the Covid-19 virus. Although in practice the information conveyed has not maximally influenced changes in people's behavior during a pandemic, however, in theory this step is in accordance with prior research which shows that in a pandemic situation, public communication aims to gain public trust [29].

As described in previous research which shows the importance of risk and emergency risk communication in a pandemic case to build a trust in society, Public communication is essential to prepare people to understand the conditions of the spread of disease, its effects, and dangers for them [29], [38]. Moreover, Indonesian society's situation and culture are diverse, so it is important for effective and efficient public communication that the community can easily understand and the goals that are expected to be achieved [30]. The biggest challenge in Indonesia is that the regional autonomy government system makes local governments also have an important role in 
disseminating and conveying information to the public. However, unfortunately, the delivery of information and public communication did not seem to be a priority at the beginning of the pandemic. It can be seen from the seven directives of the president that have not included the importance of delivering accurate, effective, and efficient information. Evidence in prior research is proposed to extend risk communication resources and principles and incorporate communication tools and guidance for long-term behavioral change and social movement into existing outbreak communication guidelines, especially in developing countries [29].

Another big challenge in the risk communication process in a pandemic situation in a regional autonomy system is that the tiered information between the central government and local governments often collides with different interests. Thus anticipating these obstacles requires special tools that can accommodate national and regional interests. The regional autonomy law does not contain specific provisions governing regional governments' authority in delivering information to the public. Therefore, the existence of tools and guidance for local governments in conveying information to the public about the situation and risk of a pandemic condition is crucial to provide good information and understanding for the public to be aware of the real situation. Furthermore, the integration of risk communication becomes a priority in the early days of a pandemic. In this period, information becomes crucial to contain the spread of a pandemic disease. Risk communication that is not integrated tends to create different community perceptions, giving the impression that the lack of coordination between government agencies that impacts the community does not consider the dangers of a pandemic situation.

If we reflect on the case of the pandemic influenza (H1N1) in 2009, many developing countries felt that engaging at the group level was a challenge and needed help to prepare for community-level communication on behavior change [29], [39]. Therefore, learning from past pandemic situations, integrated and continuous risk communication is essential because people's behavior and attitudes will be complicated to change in a short time. The exciting thing in the Covid-19 case in Indonesia is that the style of public communication of each regional leader has different characteristics; for example, the Governor of West Java Province. He actively communicates his policy developments through social media accounts, as well as the Governor of Jakarta.

\subsection{A Political Ecology in Pandemic Situation}

Inevitably, a pandemic situation will also involve many interests, including political interests [33]. One of the crucial things in a regional autonomy system is that the policy cannot be separated from regional political initiatives. Therefore, the interests of containment and prevention of spread will also be determined by politics in the regions. The socio-culture of the community also determines how the local community interacts with its environment socially. Evidence in previous research concerning patterns of local responses to outbreaks, of culture, and patterns of community organization revealed in the network of local ties between organizations and their conventional workings [1], [34], [40]. This situation indicates that local authorities' role in community behavior needs to be encouraged and prepared carefully.

Politics in the aftermath of disease continues to form a reaction of the group to system security, performance evaluation, and distributing of responsibility, punishments and rewards, and organizational distribution [23], [32], [41]. The role of politics in controlling and controlling policies will have a significant influence when health interests are the primary goal. The movement of the human population has inevitably contributed significantly to the spread of disease [36]. Therefore, this is where power politics has the authority to limit and regulate the population's movement between regions. Furthermore, in terms of medical treatment, patients exposed to Covid-19, and facilitation for health workers, political budgets are also another important matters that need attention from the government.

The state and regional revenue and expenditure budgets are a political agreement between the government and the people represented by the people's representative council. Therefore, it is necessary to have good political communication between the government and the people's representative council so that every pandemic case handling program will receive consistent support. The regulation of behavior regulated through rules issued and applied by the government to the community requires socialization and strong political support to have the right effect and follow its 
objectives. In a regional autonomy system, the role of politics cannot be separated, because direct regional leader elections make handling the Covid-19 pandemic a tool to overthrow or maintain power. Therefore, the guidance and tools are needed not to use the pandemic situation as a political arena for the incumbent and his political opponents.

The regional autonomy system shows that the Regional leader's role as a policymaker for handling the pandemic situation in the region is largely determined by the capacity of the resources in the region, both human and infrastructure resources. The difference in the condition of infrastructure from the different areas means that each region's policies are determined by the initiatives undertaken by each regional leader. In handling cases at the beginning of a pandemic, the response of the regions is still awaiting a policy made by the central government. Based on table 1, it can be seen that in early March, except for Jakarta, there were practically no local governments that declared to prepare for an emergency for the pandemic disease.

\section{Conclusion and policy recommendation}

Learning from experience gained in the 2002-2004 pandemic case SARS, which shows that without a vaccine, both single and multiple government interventions have a substantial impact on efforts to contain the spread of the virus [42]. Therefore, the capacity and capability of government at every level become important in preventing the spread of a pandemic disease. The city blockade action carried out by the Wuhan City Government Since January 23, 2020, should have been a warning to other cities and countries in the world about the danger of spreading Covid-19. However, it is a challenge for countries with regional autonomy systems such as Indonesia. The issue of regional readiness, economic factors, and social characteristics is a major consideration for Indonesia's Government in implementing a system of preventing the spread of the Covid-19 pandemic disease. WHO's interim guidance concerning prevention and containment of the pandemic spread requires cohesiveness from government institutions. Therefore, policy recommendations that need to be prepared in the future are as follows (1) Preparation for contagious disease emergencies, especially pandemic diseases, requires strengthening local government institutions by training and preparing tools and guidance integrated between the central government and local governments sustainabl; (2) The response at the beginning of the pandemic period is crucial. Therefore, a special instrument is needed to be used in efforts to prevent and contain the spread of a pandemic disease, thus for future special instrument for pandemic case should be develop and prepared; (3) Risk communication is essential in a pandemic case. Therefore, increasing the local government's capacity in terms of integrated public communication with the central government is necessary to be prepared on an ongoing basis, including regulating the use of mass media and internet media as a means of delivering information; (4) Legal frameworks for refocusing budgets in the regions need to be prepared when fast handling is needed at the start of a pandemic to accelerate handling at the local government level. Based on experience gained in pandemic case, which shows that multiple government interventions substantially impact efforts to contain the spread of the virus. However, this review is limited to the government's response at the beginning of the Covid-19 pandemic situation in Indonesia and its challenges in government systems' regional autonomy. To understand the government's response and its impact, more comprehensive research is highly recommended to get a complete picture at the beginning of the pandemic and during the pandemic case occurs.

\section{References}

[1] A. Kamradt-Scott, "The politics of medicine and the global governance of pandemic influenza," Int. $J$. Heal. Serv., vol. 43, no. 1, pp. 105-121, 2011.

[2] World Health Organization - WHO, "A Safer Future: Global Public Health Security in the 21ST Century.," 2007.

[3] R. Darmawan, "The practices of decentralization in Indonesia and its implication on local competitiveness," 2008.

[4] R. L. Holzhacker, R. Wittek, and J. Woltjer, "Decentralization and governance for Sustainable society in Indonesia," in Decentralization and Governance in Indonesia, () Springer International Publishing Switzerland 2016, 2015, pp. 1-29. 
[5] S. Rostiyanti, V. Coffey, M. . Pangeran, and R. Tamin, "A Critical Perspective of The Indonesian Institutional Framework for PPP Toll Roads," in PPP International conference 2013 - Body of Knowledge University of Central Lancashire (UCLAN) Preston, UK COST Action TU1001 : Public Private Partnerships in Transport, 2013, no. 2013, pp. 415-422.

[6] N. A. Phelps, T. Bunnell, and M. A. Miller, "Post-disaster economic development in Aceh: Neoliberalization and other economic-geographical imaginaries," Geoforum, vol. 42, no. 4, pp. 418426, 2011.

[7] R. Simarmata, "Regional Autonomy and the Character of Local Government Laws and Regulations New Pressures on the Environment and Indigenous Communities A Preliminary Diagnosis," in International Association for the Study of Common Property 9th Biennial Conference, Victoria Falls, Zimbabwe, 2002, pp. 3-14.

[8] M. A. Miller, "Rebellion and Reform in Indonesia Jakarta's Security and Autonomy Policies in Aceh," J. Curr. Southeast Asian Aff., vol. 28(4), no. 2009, pp. 145-151, 2009.

[9] M. A. Imron, "Regional Autonomy Proliferation of Region and Pseudo Local Government in Indonesia," J. Kawistara, vol. 1, no. 2, pp. 1-1, 2011.

[10] M. Rifai, "Regional autonomy and globalization:A development model study in Karawang Regency," $J$. Polit. Indones., vol. 2, no. Juli 2017, pp. 15-28, 2017.

[11] S. Butt, "Regional Autonomy and Legal Disorder: Proliferation of Local Laws in Indonesia," Sing. J. Leg. Stud., vol. 32, no. March, pp. 177-191, 2010.

[12] W. H. Frederick and R. L. Worden, Eds., Indonesia a country study, 6th editio. Washington, D.C.: The United states Government Library of Congress, 2011.

[13] M. A. Miller, "Decentralizing Indonesian City Spaces as New 'Centers," Int. J. Urban Reg. Res., vol. 37, no. 3, pp. 834-848, 2013.

[14] H. Kagami, "Regional Autonomy in Process: A Case Study in Bali 2001-2003," Asian African area Stud., vol. 5, no. 1, pp. 46-71, 2005.

[15] N. Novira, "Political ecology of land use change in Indonesia," Geophys. Reserach Abstr., vol. 16, 2014.

[16] F. Ardiansyah, A. A. Marthen, and N. Amalia, "Forest and land-use governance in a decentralized Indonesia: A legal and policy review," Bogor, 2015.

[17] B. Riadi, B. Barus, Widiatmaka, M. Yanuar, and B. Pramudya, "Identification of flood area in the coastal region using remote sensing in Karawang Regency, West Java," in IOP Conference Series: Earth and Environmental Science, 2018, vol. 162, no. 1.

[18] L. P. Smeru, "Reflections on Regional Autonomy Implementation and Sustainable Management of Natural Resources (in Bahasa Indonesia)," in Proceeding seminar and workshop Regional Riau Mandiri - SMERU, 2003, pp. 2-5.

[19] H. Hasim, "Lake Limboto Management Policy in the Perspective of Political Ecology," Publik (Jurnal Ilmu Adm., vol. 7, no. 1, pp. 44-52, 2018.

[20] K. A. Arini, "Examining the Relationship between Government Administration and the Causes of Ecological Crisis Judging from the Political Format and Practices of Natural Resource Management (in Bahasa Indonesia)," Muhammadiyah University of Yogyakarta, 2019.

[21] L. Romli, Regional autonomy and local public representatives picture (in Bahasa Indonesia), 1st ed. Yogyakarta: Pustaka Pelajar, 2007.

[22] J. S. Kamasah and C. Dzuvor, "Economic Impacts of Wuhan 2019 - nCoV on China and the World Economic impacts of Wuhan 2019 - nCoV on China and the world," J. Med. Virol., no. February, pp. $1-3,2020$.

[23] A. Kamradt-Scott and A. Kamradt-Scott, "The Politics of Pandemic Influenza Preparedness," Oxford Handb. Glob. Heal. Polit., no. April, pp. 529-550, 2018. 
[24] C. Mcinnes, "WHO's next? Changing authority in global health governance after Ebola," Int. Aff., vol. 91, no. 6, pp. 1299-1316, 2015.

[25] C. McInnes and K. Lee, "Framing and global health governance: Key findings," Glob. Public Health, vol. 7, no. SUPPL. 2, 2012.

[26] M. I. Meltzer, N. J. Cox, and K. Fukuda, "The economic impact of pandemic influenza in the United States: Priorities for intervention,” Emerg. Infect. Dis., vol. 5, no. 5, pp. 659-671, 1999.

[27] C. I. Hovland and W. Weiss, "The influence of source credibility on communication effectiveness," Public Opin. Q., vol. 15, no. 4, pp. 635-650, 1951.

[28] C. K. Atkin and R. E. Rice, "Theory and Principles of Public Communication Campaigns," in Public Communication Campaigns, 55 City Road, London: Sage Publications, Ltd., 2013, pp. 2-19.

[29] T. Abraham, "Lessons from the pandemic: the need for new tools for risk and outbreak communication," Emerg. Health Threats J., vol. 4, 2011.

[30] D. McQuail, Mcquail's Mass Communication Theory, 6th ed. ISAGE, 2011.

[31] R. Keil, “Urban political ecology," Urban Geogr., vol. 24, no. 8, pp. 723-738, 2003.

[32] M. Turshen, “The political ecology of diseases,” pp. 45-59, 1977.

[33] L. Kapiriri and A. Ross, "The Politics of Disease Epidemics: a Comparative Analysis of the SARS, Zika, and Ebola Outbreaks,” Glob. Soc. Welf., vol. 7, no. 1, pp. 33-45, 2020.

[34] P. Antoine de Bengy and K. Sonja, “'Desease Knows No Borders': Pandemics and the Politics of Global Health Security," in Pandemics, Publics, and Politics: Staging Responses to Public Health Crises, 1st ed., K. Bjørkdahl and B. Carlsen, Eds. Palgrave Pivot, 2019, pp. 59-75.

[35] Y. Huang and C. J. Smith, "China 's Response to Pandemics: From Inaction to Overreaction," Eurasian Geogr. Econ., vol. 51, no. 2, pp. 162-183, 2010.

[36] M. U. . Kraemer et al., "The effect of human mobility and control measures on the COVID-19 epidemic in China," Science (80-. )., vol. 368, no. May, pp. 493-497, 2020.

[37] R. Djalante, J. Lassa, D. Setiamarga, A. Sudjatma, and M. Indrawan, "Review and analysis of current responses to COVID-19 in Indonesia: Period of January to March 2020 Progress in Disaster Science Review and analysis of current responses to COVID-19 in Indonesia : Period of January to March 2020 㶦," Prog. Disaster Sci. J., vol. 6, no. March, 2020.

[38] World Health Organization, "Critical preparedness , readiness and response actions for COVID-19 .," Interim Guid., no. March, pp. 1-3, 2020.

[39] World Health Organization - WHO, "Urgent Support for Developing Countries ' Responses to the H1N1 Influenza Pandemic," 2009.

[40] N. C. Leitão, "The impact of foreign direct investment on economic growth: the Portuguese experience," Theor. Appl. Econ., vol. XX, no. 2013, pp. 51-62, 2013.

[41] K. P. Schwirian, “The Political Ecology Of Plague In The Global Network Of Cities: The SARS Epidemic Of 2002 - 2003," Res. Urban Policy, vol. 10, no. 06, pp. 241-268, 2003.

[42] Y. Qiu, X. Chen, and W. Shi, "Impacts of social and economic factors on the transmission of coronavirus disease 2019 (COVID-19) in China," J. Popul. Econ., 2020. 